Altai State University

Acta 3iologica Gibirica

Journal of Biology

Founded in 2015

\title{
Review of the predaceous diving beetles of the genus Hydaticus Leach, 1817 (Coleoptera: Dytiscidae) of Kazakhstan
}

\section{I.I. Temreshev}

LLP "Zh. Zhiembayev Kazakh SRI of Plant Protection and Quarantine named", Ministry of Agriculture of Republic of Kazakhstan, 050070, Almaty, Nauryzbaysky district, md. Rahat, Kultobe street, 1, Kazakhstan

temreshev76@mail.ru

The genus Hydaticus Leach, 1817 (Coleoptera: Dytiscidae) in Kazakhstan is reviewed including diagnoses, illustrations, distributions, and natural history. An annotated checklist of the 7 species of the genus occurring in Kazakhstan is presented. They belong to the subgenus Hydaticus (s. str.) with 4 species: $H$. aruspex Clark, 1864, $H$. continentalis J. BalfourBrowne, 1944, H. seminiger DeGeer, 1774, H. transversalis Pontoppidan, 1763, and to the subgenus Prodaticus Sharp, 1882 with 3 species: H. grammicus Germar, 1827, H. pictus Sharp, 1882, H. ponticus Sharp, 1882. H. aruspex and H. seminiger are recorded in Kazakhstan for the first time.

Key words: predaceous diving beetles, checklist, Hydaticus, Dytiscidae, genus, fauna, distribution, Kazakhstan.

\section{Обзор жуков-плавунцов рода Hydaticus Leach, 1817 (Coleoptera: Dytiscidae) Казахстана}

\author{
И.И. Темрешев \\ ТОО «Казахский Научно-исследовательский институт защиты и карантина растений им. Ж. \\ Жиембаева» Министерства сельского хозяйства Республики Казахстан \\ 050070, г. Алматы, Наурызбайский район, мкр. Рахат, ул. Култобе, 1, Республика Казахстан \\ temreshev76@mail.ru
}

\begin{abstract}
Дан обзор видов жуков-плавунцов рода Hydaticus Leach, 1817 фауны Казахстана, включающий данные по их распространению, морфологии, экологии, изображения жуков. Приведен аннотированный список 7 видов рода, встречающихся в Казахстане. Подрод Hydaticus (s. str.) представлен 4 видами: H. aruspex Clark, 1864, H. continentalis J. Balfour-Browne, 1944, H. seminiger DeGeer, 1774, H. transversalis Pontoppidan, 1763, подрод Prodaticus Sharp, 1882 - 3 видами: H. grammicus Germar, 1827, H. pictus Sharp, 1882, H. ponticus Sharp, 1882. H. aruspex и H. seminiger указываются для Казахстана впервые.

Key words: жуки-плавунцы, аннотированный список, Hydaticus, Dytiscidae, род, фауна, распространение, Казахстан.
\end{abstract}

\section{Введение}

Род Hydaticus Leach, 1817 принадлежит к трибе Hydaticini Sharp, 1882 подсемейства Dytiscinae Leach, 1815 семейства Dytiscidae Leach, 1815 (Nilsson, 1981). Род ранее включал 7 подродов, но затем они были сведены в 2 подрода - Hydaticus Leach, 1817 (Icmaleus Gistel, 1856) и Prodaticus Sharp, 1882 (Guignotites Brinck, 1943, Isonotus 
Guignot, 1936, Hydaticinus Guignot, 1950, Pleurodytes Regimbart, 1899) (Miller et al., 2009). Жуки средних и крупных размеров (8.5-20.5 мм), одни из наиболее ярко окрашенных представителей семейства плавунцов, с разнообразным в зависимости от вида узором из пятен и полос (Nilsson, 1981; Nilsson, Holmen, 1995; Miller et al., 2009). Отросток переднегруди на вершине округлен. Метастернальные крылья узкие, язычковидные, с прямолинейным наружным краем. Нижний край 1-4 метатарсомеров густо усажен короткими прилегающими желтыми щетинками. Задний наружный коготок вдвое короче внутреннего и сильнее загнут на конце. Передние голени $\widehat{\jmath}$ очень короткие треугольные, без концевой шпоры. На присасывательном диске 3-4 крупные присоски и небольшое число мелких, убывающих по величине по направлению к вершине. Средние лапки $\delta$ также снабжены довольно крупными присосками (Nilsson, 1981; Nilsson, Holmen, 1995; Zaitzev, 1953; Tsalolikhin, 2001).

Представители рода Hydaticus известны практически со всех континентов мира, за исключением Антарктиды. Подавляющее большинство их населяет тропическую зону Африки, немного видов в фауне Америки и Австралии. Обитают они преимущественно в мелких стоячих водоемах с обильной водной растительностью, но есть и населяющие медленно текущие водоемы (реки, ручьи, каналы и т.п.). Некоторые виды иногда бывают довольно многочисленными (Zaitzev, 1953; Tsalolikhin, 2001; Nilsson, 1981; Nilsson, Holmen, 1995; Miller et al., 2009). Bceго в мировой фауне насчитывается 152 вида рода Hydaticus (Nilsson, Hajek, 2018a). Для Палеарктики на сегодняшний день указано 36 видов (Nilsson, Hajek, 2018a, b). Для Казахстана согласно последней версии Каталога плавунцов Палеарктики (Nilsson, Hajek, 2018b) и работе М. Пржевозны (Przewoźny, 2018) было отмечено всего 3 вида плавунцов данного рода, причем видовой состав в обоих указанных источниках различается. Кроме того, распространение и численность отдельных видов рода Hydaticus в разных регионах страны не были уточнены.

\title{
Материал и методы
}

Материал собирался нами в разных областях Казахстана с 1996 по 2018 гг. При сборе материала применялись стандартные энтомологические методики - лов на свет, сбор водным сачком, ручной сбор и отлов с помощью воронковых ловушек. Кроме собственных сборов, были обработаны коллекционный фонд Института зоологии КН МОН РК, Казахского НИИ Защиты и карантина растений им. Ж. Жиембаева, и сборы коллег из Казахстана, Россиийской Федерации и Кыргызстана. Для видовой идентификации жуков, уточнения их синонимии, а также биологии и распространения использовались источники из списка литературы (Jacobson, 1905-1915; Zaitzev, 1953; Tsalolikhin, 2011; Nilsson, 1981; Nilsson, Holmen, 1995; Löbl, Smetana, 2003; Nilsson, Hajek, 2018a, b; Przewoźny, 2018). Часть данных уже указывалась нами ранее в некоторых работах (Temreshev, 2014a, b; 2015a, b, c, d; 2016; 2018; Temreshev, Esenbekova, 2013; Temreshev, Kolov, 2013), но в настоящей статье также приводится в целях облегчить читателю уточнение распространения и численности видов в Казахстане без дополнительного поиска данных работ. Материал, который ранее не приводился, отмечен знаком*.

В приводимом материале Западно-Казахстанская, Атырауская, Актюбинская, Мангыстауская, Костанайская, Северо-Казахстанская, Акмолинская, Павлодарская, Восточно-Казахстанская, Карагандинская, Алматинская, Жамбылская, Южно-Казахстанская и Кызылординская области Республики Казахстан сокращены как ЗКО, АТО, АКТО, МО, КОО, СКО, АКО, ПО, ВКО, КАО, АО, ЖО, ЮКО и КО. Также сокращены фамилии сборщиков: ИТ - И.И. Темрешев, ВК - В.А. Кащеев, ЕИ - Е.В. Ишков, БК - Б.К. Кульмагамбетов, ПЕ - П.А. Есенбекова, ЮД - Ю. Дьячков, СО С.В. Овчинников, ПЛ - П.А. Лер, ЛК - Л.Д. Казенас; ЕБ - Е. Бикбаев, и некоторые административные и географические единицы: обл. - область, р-н - район, г. - город, п. - поселок, окр. - окрестности, оз. - озеро; р. река, вдхр. - водохранилище, пер. - перевал, ущ. - ущелье, хр. - хребет, п-ов - полуостров, кх - крестьянское хозяйство.

\section{Результаты}

В результате проведенных исследований был составлен приводимый далее аннотированный список жуковплавунцов рода Hydaticus фауны Казахстана.

\author{
Отряд Coleoptera Linnaeus, 1758 \\ Подотряд Adephaga Schellenberg, 1806 \\ Надсемейство Dytiscoidea Leach, 1815 \\ Семейство Dytiscidae Leach, 1815 \\ Подсемейство Dytiscinae Leach, 1815 \\ триба Hydaticini Sharp, 1882 \\ Род Hydaticus Leach, 1817
}

\section{Подрод Hydaticus Leach, 1817}

Голова и переднеспинка обычно с темными пятнами; низ черный. Задние бедра на нижней стороне в густых осповидных точках. Задние бедра длинные, покрыты углубленными точками, а между ними - мелкими точками. Длина 12-15 мм (Zaitzev, 1953; Nilsson, 1981; Nilsson, Holmen, 1995; Tsalolikhin, 2011). 
Hydaticus aruspex Clark, 1864 (H. americanus Sharp, 1882, H. laevipennis Thomson, 1867, H. laeviusculus Poppius, 1906, H. modestus Sharp, 1882, H. rugosus Poppius, 1905). Длина 9-10 мм. У обоих полов надкрылья имеют желтую боковую кайму и желтые продольные линии, кроме того - желтую перевязь у основания, часто разорванную на отдельные пятна. Иногда встречаются особи с сильно редуцированными желтыми продольными линиями. Черная полоса у основания переднеспинки достигает ее середины, но не заходит дальше. Бока переднеспинки и надкрылий самки с резко выраженными глубокими морщинками. На надкрыльях морщинки занимают 2/3 всей поверхности. Длина наружного метатарсального коготка самца равна 1/3 внутреннего; у он самки значительно больше 1/2 внутреннего, у основания широкий. Низ черный. Жук удлиненновальный, суженный (рис. 1). В разнообразных стоячих водоемах.

Распространение. Европа, Сибирь, Дальний Восток, Китай, Япония, Северная Америка. - Северный и Центральный Казахстан.

Материал: *1 o - 12.08.1998, СКО, окр. г. Петропавловск, пойменный водоем у р. Ишим, лов сачком, ИТ; *1 $\delta$ 1 q - 6.07.2013, АКО, Коргалжынский р-н, оз. Султанкельды, воронковая ловушка, ИТ.

Примечание. Для Казахстана вид указывается впервые. Возможно, распространен на территории республики гораздо шире, но для уточнения этого вопроса требуются дополнительные исследования.

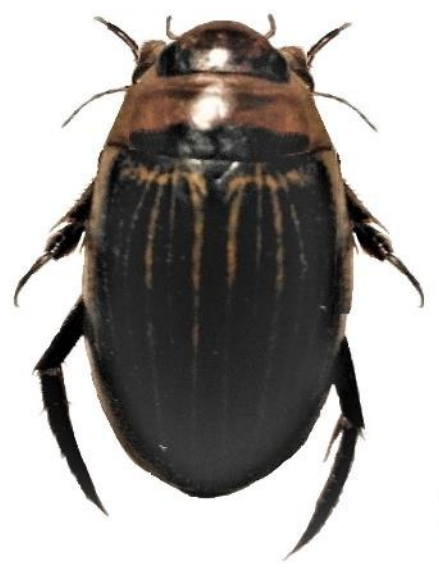

a

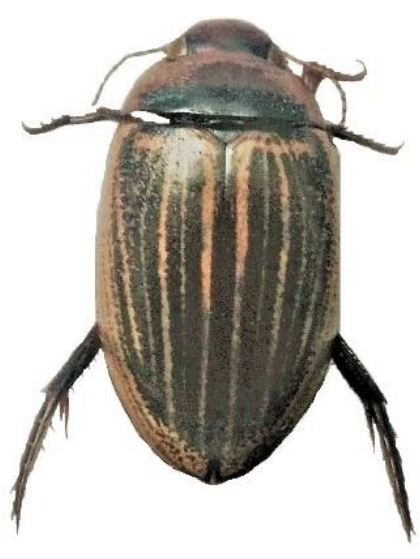

$\mathrm{b}$

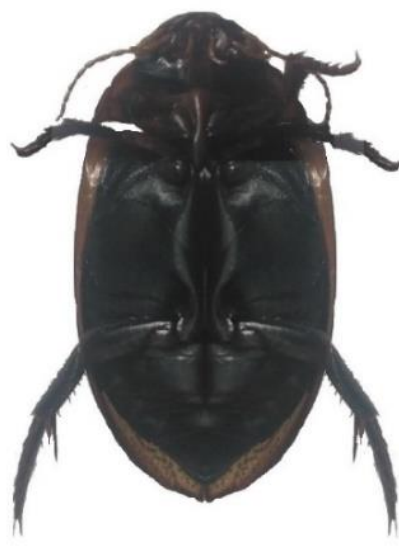

C

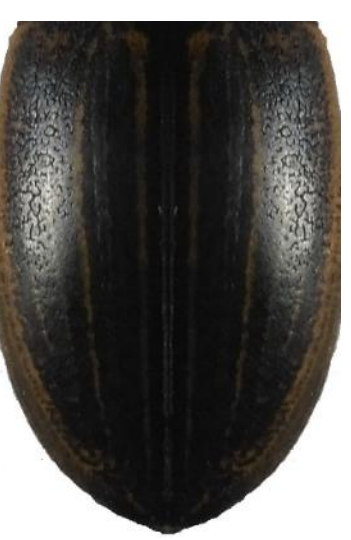

d

Рис. 1. Hydaticus aruspex, внешний вид (а - самец, вид сверху; b - самка, вид сверху; с - вид снизу; d - надкрылья самки)

Hydaticus continentalis J. Balfour-Browne, 1944 ( $H$. stagnalis Fabricius, 1787). Длина 13-14 мм. У обоих полов надкрылья имеют желтую боковую кайму и желтые продольные линии. Черная полоса у основания переднеспинки не доходит до ее середины. Длина наружного метатарсального коготка немного больше 1/2 внутреннего; у самки он узкий у основания. У самца протарсальные коготки довольно сильно изогнуты у основания. Бока переднеспинки самки со слабо выраженными морщинками. Низ черный или смоляно-бурый. Жук коротко- и широковальный (рис. 2). Обитает в основном в заросших временных водоемах открытых ландшафтов, но может жить и в постоянных стоячих водоемах.

Распространение. Европа, Западная Сибирь. - Западный, Северный и Центральный Казахстан.

Материал: *1 ઈิ - 21.07.1959, КАО, Жанааркинский р-н, горы Коксенгир, ПЛ; *1 ф - 3.07.1996, КОО, окр. г. Костанай, заросший стоячий водоем, ручной сбор, ИТ; *1 ф - 26.07.1996, АКО, окр. г. Кокшетау, оз. Копа, лов сачком, ИТ; *2 $\widehat{o} 1$ - 3.08.1996, АКО, Зерендинский р-н, окр. п. Зеренда, стоячий заросший водоем у оз. Зеренда, лов сачком, ИТ; *1 ㅇ - 19.07.1998, АКО, Целиноградский р-н, оз. Шалкар, лов сачком, ИТ; *1 1 o - 12.08 .1998$, СКО, окр. г. Петропавловск, пойменный водоем у р. Ишим, лов сачком, ИТ; *1 $\delta$ - 18.08.1998, там же, лов сачком, ИТ; *1 సे - 20.07.1998, АКО, окр. г. Кокшетау, оз. Копа, ручной сбор, Ит; *2 $\hat{\sigma}-24.06 .2000$, АКТО, Иргизский р-н, заросший берег р. Тургай, ручной сбор, Ит; *1 ๙ิ 1 q - 23.08.2000, АКТО, Иргизский р-н, окр. п. Иргиз, стоячий заросший водоем, лов сачком, ИТ; 1 q - 6.07.2013, АКО, Коргалжынский р-н, оз. Султанкельды, воронковая ловушка, ИТ; 1 ᄋ 7.07.2013, там же, воронковая ловушка, ИТ; *1 о - 5.07.2014, КАО, Шетский р-н, р. Аксу-Аюлы, заросший пойменный водоем, ручной сбор, ИТ; *1 ઈิ 1 q - 14.07.2014, там же, воронковая ловушка, ИТ; *1 Коргалжынский р-н, оз. Кокай, воронковая ловушка, ИТ; *1 § - 3.09.2014, ЗКО, Жангалинский р-н, 3 км N п. Жанакала, воронковая ловушка, ИТ; *1 о - 5.09.2014, 3КО, Жангалинский р-н, окр. п. Маштексай, на свет, ИТ.

Примечание. В Каталоге плавунцов Палеарктики 2018 (Nilsson, Hájek, 2018b) вид для Казахстана не указан вообще, хотя ранее приводился Г.Г. Якобсоном для Уральской области (Jacobson, 1905) как H. stagnalis. Эти данные подтверждают наши материалы из ЗКО. Нами был отмечен также для северной и центральной (Temreshev, 2015b) части страны. 


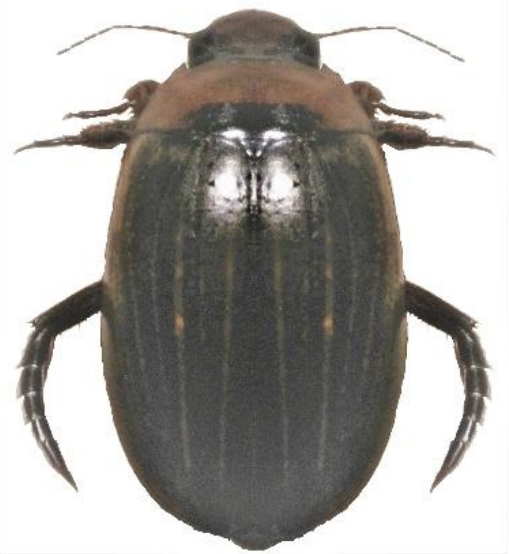

a

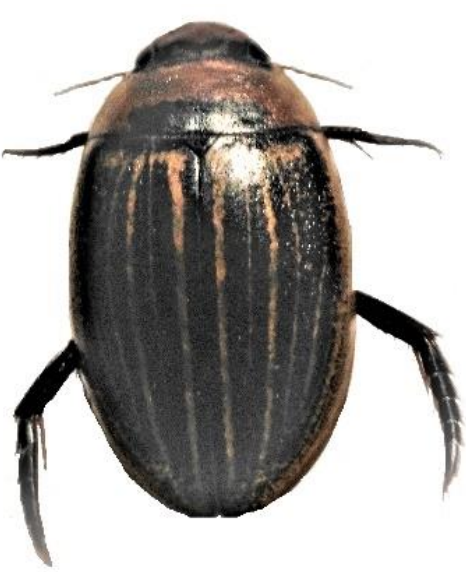

b

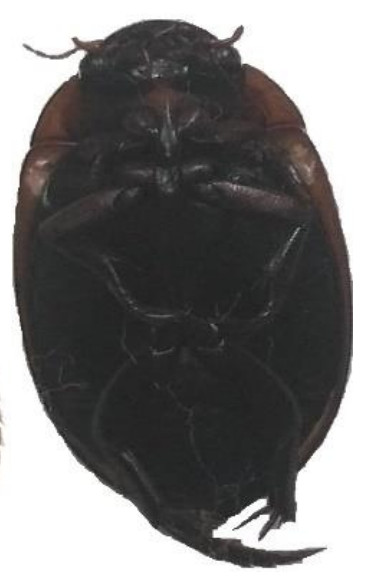

Рис. 2. Hydaticus continentalis, внешний вид (а - самец, вид сверху; b - самка, вид сверху; с - вид снизу)

Hydaticus seminiger DeGeer, 1774 (Dyticus cinctus O.F. Müller, 1776; D. danicus Gmelin, 1790; D. hybneri Fabricius, 1787; D. parapleurus Marsham, 1802; D. sexpunctatus Drapiez, 1819). Длина 13.5-15 мм. Надкрылья черные, кроме желтой боковой каймы, без полосок, самое большее с небольшим прищитковым желтым пятном. Их скульптура представлена только мелкими рассеяными черными точками. Переднеспинка более чем на 2/3 черная, иногда темная часть доходит почти до ее переднего края. Протарсальные коготки самца относительно длинные, утончены к вершине и сильно изогнуты в основной части. Низ черный (рис. 3). Чаще в стоячих водоемах с обильной растительностью, особенно в лесных, но иногда встречается в реках и ручьях. Летит на свет.

Распространение. Европа, Сибирь. - Северный, Центральный, Северо-Восточный, Восточный, Южный и Юго-Восточный Казахстан.

Материал: *1 ઈ 1 q - 4.07.1996, КОО, окр. г. Костанай, заросший стоячий водоем, ручной сбор, ИТ; *1 q 25.07.1996, АКО, Бурабайский район, оз. Текек-Коль, ручной сбор, ИТ; *1 ф - 2.08.1995, АКО, Алексеевский район, окр. п. Ивановский, в заросшем пруду в смешанном лесу, ручной сбор, ИТ; *1 ઈิ - 3.08.1996, АКО, Зерендинский р-н,

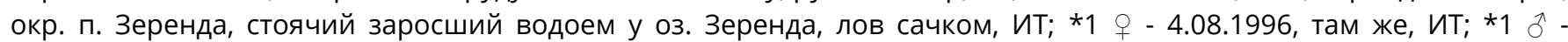
17.08.1998, СКО, окр. г. Петропавловск, пойменный водоем у р. Ишим, лов сачком, ИТ; *1 q - 27.06.2004, пО, Иртышский район, пойменный водоем у р. Иртыш, ручной сбор, ИТ; *1 ઈ- 9.06.2013, ВКО, Абайский р-н, хр. Ханчингиз, стоячий водоем, лов сачком, ПЕ; *1 ઈิ - 5.09.2013, там же, ПЕ; 1 ઈ - 27.05.2015, АО, Лепсинский р-н, ГНПП «Жонгар-Алатау», Чернореченский кордон, верховое болото, лов сачком, ИТ; *1 ф - 18.04.2017, ЖО, Шуйский р-н, п. Беткайнар, на лету, Ит.

Примечание. В Каталоге плавунцов Палеарктики 2018 (Nilsson, Hájek, 2018b) для Казахстана не указан. Был отмечен нами для юго-востока Казахстана (Temreshev, 2018.) Для юга страны первая находка. Редок.

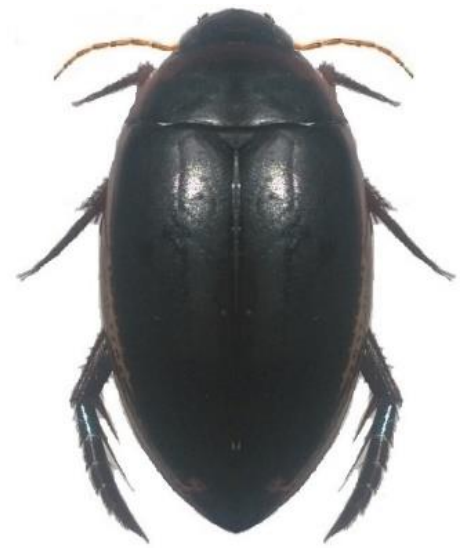

a

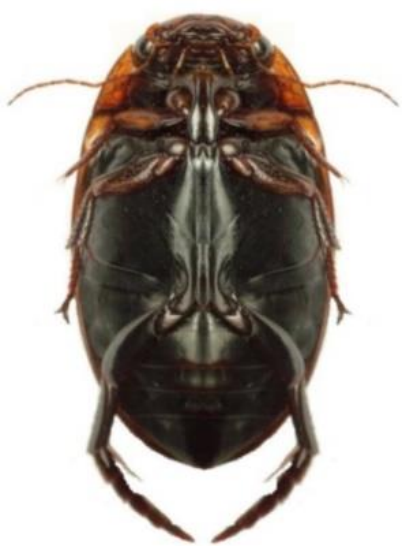

b

Рис. 3. Hydaticus seminiger, внешний вид (а - вид сверху, b - вид снизу)

Hydaticus transversalis Pontoppidan, 1763 (H. punctipennis Thomson, 1867; $H$. degeneratus Westhoff, $1882 ; H$. interruptemaculatus Gerhardt, 1899; H. sahlbergi Zaitzev, 1905; H. laevisculptus Zaitzev, 1910; H. inderiensis Zaitzev, 1915). Длина 12-13.5 мм. Надкрылья черные, на каждом в первой трети имеются желтые поперечные перевязи. Иногда встречаются темные формы с сильно или полностью редуцированными перевязями (форма degeneratus Westh.). Скульптура надкрылий представлена как крупными, так и мелкими точками. Переднеспинка чуть менее чем наполовину черная, иногда темная часть заходит за середину, но никогда не бывает 2/3 ее длины. Протарсальные 
коготки самца короткие и равномерно закруглены. Низ красно-бурый (рис. 4). Предпочитает постоянные стоячие водоемы с обильной растительностью в открытых ландшафтах. Летит на свет.

Распространение. Европа, Малая Азия, Ближний Восток, Западная Сибирь, Индия. - Западный, Северный, Северо-Восточный, Центральный и Юго-Восточный Казахстан.

Материал: *1 § 2 क - 26.07.1996, АКО, Бурабайский район, оз. Текек-Коль, ручной сбор, ИТ; *1 0 - 5.08.1996, АКО, Зерендинский р-н, окр. п. Зеренда, заросший пруд в березовом лесу, ручной сбор, ИТ; *1 $\widehat{0}-17.08 .1998$, СКО, окр. г. Петропавловск, пойменный водоем у р. Ишим, лов сачком, ИТ; *1 1 o - 25.06.2004, ПО, Качирский район, в заросшем пруду, ИТ; *1 ઈ - 12.06.2009, ПО, 25 км В от п. Шидерты, оз. М. и Б. Майсор, ПЕ; *1 q - 3.10.2011, МО, Макатский р-н, 5 км С п. Доссор, N 47 30' 57.4" Е 52 58' 45.7", ЕБ; *1 о - 7.10.2011, МО, Тупкараганский р-н, месторождение Каламкас, N 45¹6'48.1" Е 51²3'44.8", ЕБ; 1 ภ 1 ㅇ - 27.05.2015, АО, Лепсинский р-н, ГНПП «ЖонгарАлатау», Чернореченский кордон, верховое болото, лов сачком, ИТ.

Примечание. В Каталоге плавунцов Палеарктики (Nilsson, Hájek, 2018b) указан только для запада Казахстана. Ранее указывался оттуда Ф.А. Зайцевым (Zaitzev, 1953) и другими авторами (Tsalolikhin, 2001) как самостоятельный вид $H$. inderiensis. Для севера и северо-востока Казахстана указывается впервые. Для юго-востока страны первая находка была сделана нами в 2015 г. в ГНПП «Жонгар-Алатау», хр. Жетысу-Алатау (Temreshev, 2018). Редок.

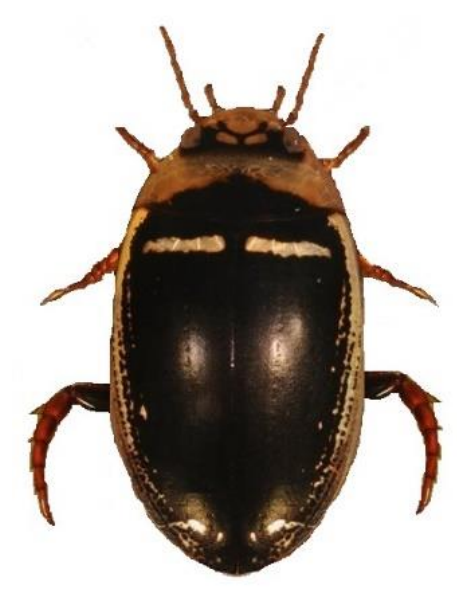

a

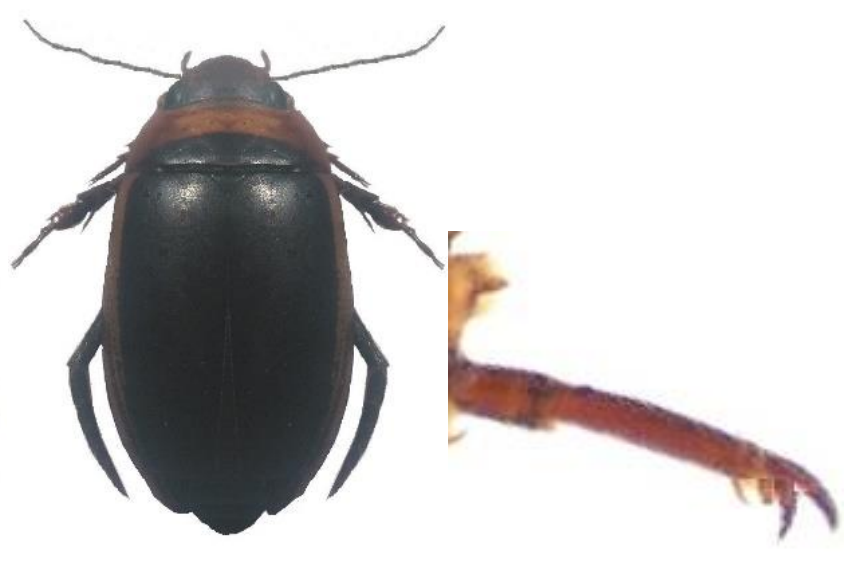

b
C

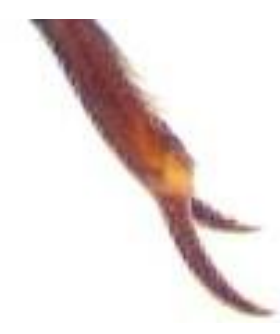

d

Рис. 3. Hydaticus transversalis, внешний вид сверху (а - типичная форма; b - темная форма; с - протарсальные коготки самца темной формы; d - метатарсальные коготки самца темной формы)

\section{Подрод Prodaticus Sharp, 1882}

Голова и переднеспинка, кроме темной полоски у основания, одноцветные, желтые или желтоватокоричневые, иногда с черной каймой, либо темные с со светлыми пятнами и полосками. Низ тела ржаво-желтый или коричневый. Задние бедра почти лишены точек. Задние голени короткие; между глубокими удлиненными точками на них мелких точек нет. Длина 8.5-13.5 мм (Zaitzev, 1953; Tsalolikhin, 2011).

Hydaticus grammicus Germar, 1827 (Dytiscus lineolatus Menetries, 1832; H. nigrovittatus Clark, 1864). Длина 9-11 мм. Надкрылья темные с тонкими продольными желтыми линиями, сближенными попарно. С внешней стороны темный фон распадается на более или менее крупные продолговатые пятнышки. Жук короткоовальный, сильно блестящий, снизу красновато-желтый (рис. 5). В разнообразных стоячих, в т.ч. солоноватоводных и соленых водоемах; периодически встречается в медленно текущих реках и ручьях, каналах и арыках. Активно летит на свет.

Распространение. Европа, Турция, Туркменистан, Киргизия, Узбекистан, Афганистан, Китай, Индия, Япония, Северная Корея. - Юго-Западный, Центральный, Южный и Юго-Восточный Казахстан.

Материал: *1 ઈ- 22.06.1961, КО, колхоз Комсомол, ЛК; *1 ઈิ-10.09.1984, МО, Тупкараганский р-н, п-ов Бузачи, ур. Кошак, пЛ; 2 ઈ - 23.07.1984, КО, Аральский р-н, оз. Камыслыбас, на свет, ВК; *1 ઈ - 11.05.1989, АО, Балхашский рн, окр. Баканаса, Илийский ботсад, на свет, ЕИ; *1 $q$ - 22.07.1989, там же, на свет, ЕИ; *3

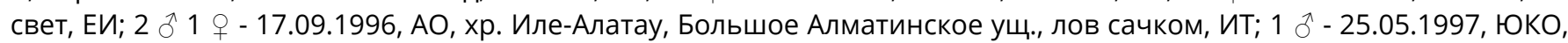
Арысский р-н, окр. п. Арысь, СО; *1 § 3 q - 10.08.2004, АО, Жамбылский р-н, окр. с. Айдарлы, на свет, ИТ; 1 ๙ 1 q 14.08.2004, АО, Панфиловский р-н, пойма р. Осек, болото, ИТ; *1 ઈ- 5.08.2009, ЖО, окр. г. Тараз, пойма р. Талас, ПЕ; 2 ๙ 3 o - 3.06.2010, АО, Кербулакский р-н, Поющий бархан, Улькен Калкан, берег р. Иле, на свет, ИТ; *1 ㅇ 3.06.2010, АО, Кербулакский р-н, горы Катутау, 135 км Ю от п. Сарозек, на свет, ИТ; 1 q - 19.04.2012, ЮКО, Шардаринский р-н, пойма р. Сырдарья, окр. с. Жаушыкум, ПЕ; 1 ठ - 29.04.2012, ЮКО, Мактааральский р-н, окр. п. Достык, ПЕ; 1 ઈิ 2 о - 25.04.2012, ЮКО, Мактааральский р-н, окр. п. Асыката, ПЕ; *1 $\hat{\sigma}-27.04 .2012$, ЮКО, Мактааральский р-н, окр. п. Асыката, ПЕ; 2 q - 19.05.2012, ЮКО, Тюлькубасский р-н, пойма р. Арысь, ручной сбор,

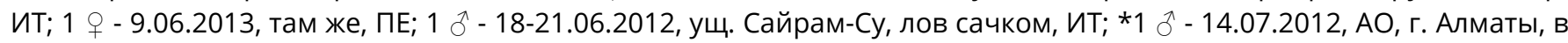


заводи р. Есентай, под камнем, ручной сбор, Ит; 1 ઈ - 25.07.2012, АО, хр. Иле-Алатау, ущ. Кимасар, в пруду, ручной сбор, ИТ; *1 ઈ 1 q - 14.08.2012, ЮКО, Мактааральский р-н, п. Асыката, пойменные водоемы, ПЕ; 1 q - 2.09.2012, АО, хр. Иле-Алатау, Каскеленское ущ., под камнем в ручье, ручной сбор, ИТ; 2 q - 12.05.2013, ЖО, Таласский р-н, пойма р. Тамды, ручной сбор, ИТ; 1 ф - 29.05.2013, ЮКО, Мактааральский р-н, п. Ынтымак, ПЕ; 1 § - 9.06.2013, ЮКО, Мактааральский р-н, окр. п. Асыката, ПЕ; 1 ภ 1 ф - 11.06.2013, ЮКО, Мактааральский р-н, пойма р. Сырдарья, ПЕ; 1 ô - 27.07.2013, АО, Саркандский р-н, окр. п. Сарканд, р. Сарканд, Ит; 1 § 1 о - 10.05.2014, окр. п. Шаян, временный водоем, лов сачком, ИТ; *1 § 1 q - 25-26.07.2014, КАО, Актогайский р-н, котлован с водой в степи 190 км Ю от г.

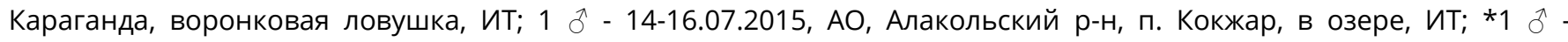
19.06.2016, АО, Панфиловский р-н, окр. п. Байсерке, в пруду, Ит; *3 2 о - 23-24.05.2017, КО, Жанакорганский р-н, оз. Колдыколь, воронковая ловушка, ИТ; *2 ^ 1 ф - 28-29.05.2017, ЖО, Сарысуйский р-н, оз. Ынталы, воронковая

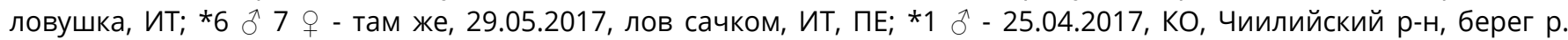

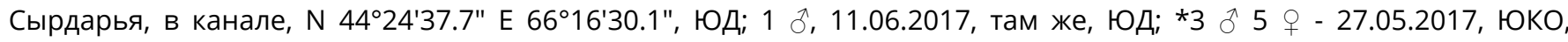
Отырарский р-н, ГНПП Сырдарья-Туркестан, 10 км СЗ п. Балтаколь, пойма р. Сырдарья, N 43 09' 20.1" Е 67 50' 36.6", ЮД; *1 q - 28.05.2017, ЮКО, Отырарский р-н, ГНПП Сырдарья-Туркестан, 12 км Ю п. Коксарай, берег Сырдарьинского канала, N 42 32' 46.1" Е 68 10' 42.7", Юд; *2 о - 08-09.06.2017, ЮКО, Сарыагашский район,

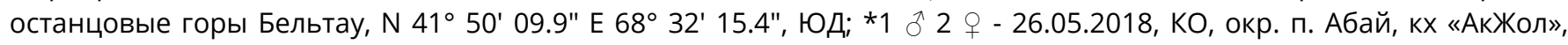
рисовые чеки, ручной сбор, ИТ; *1 1 1 1 - 27.05.2018, КО, Жанакорганский р-н, окр. п. Талап, пойменный водоем на берегу р. Сырдарья, ручной сбор, ИТ.

Примечание. Вид обычен на юге и юго-востоке Казахстана (Meldebekov, Kazenas, Bajzhanov et al., 2011; Temreshev, 2015b, с; 2016; 2018; Temreshev, Esenbekova, 2013; Temreshev, Kolov, 2013), является здесь самым массовым представителем рода Hydaticus. Заходит на юго-заапад страны (Мангыстауская область). Ранее не отмечался на территории Центрального Казахстана. Возможно, что Актогайский р-н Карагандинской области является северной границей распространения $H$. grammicus в Казахстане, а далее на север его замещает $H$. continentalis.

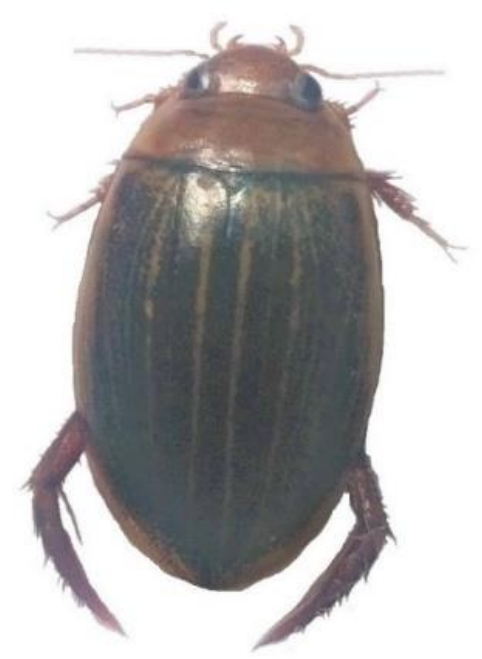

a

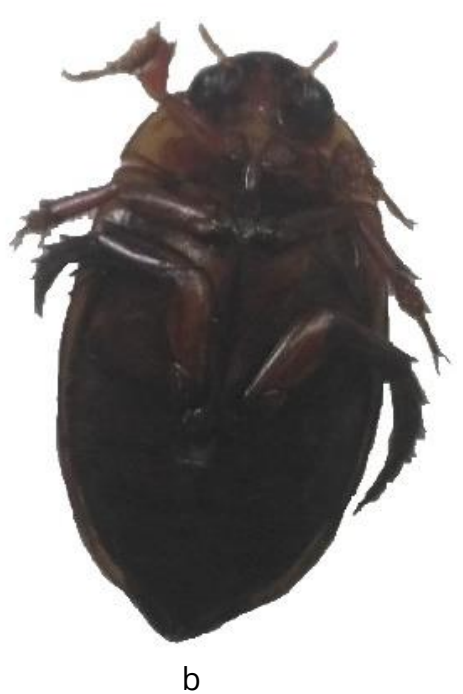

Рис. 5. Hydaticus grammicus, внешний вид (а - вид сверху, b - вид снизу)

Hydaticus pictus Sharp, 1882. Длина 14-16 мм. Надкрылья черные, с шестью ярко-желтыми пятнами неправильной формы у основания, в середине и у вершины. Наиболее крупные пятна расположены в середине надкрылий. Кроме того, на плечах с обеих сторон имеются узкие косые желтые полоски, не доходящие до середины надкрылий. Переднеспинка черная, за исключением двух узких желтых боковых полосок. Низ темнокоричневый (рис. 6). Во временных и постоянных стоячих и медленно текущих водоемах.

Распространение. Аравийский п-ов, Индия, Ирак, Сирия, Афганистан, Пакистан, Таджикистан, Туркменистан, Узбекистан. - Южный Казахстан.

Материал: 1 ภ - 30.06.2012, КО, Жанакорганский район, окр. п. Дауран-Супе, N 4342'12.9"/E 73¹7'15.17", в пересыхающем канале, ручной сбор, БК; 1 ઈิ-14.05.2013, ЮКО, Кентауский р-н, горы Каратау, N 43³1'03"/E 6850'41", 5 км западнее п. Ачисай, ущ. Тассарай, в заводи реки, под камнем, ручной сбор, ИТ; *1 $\hat{0}-19.12 .2016$, Объединенные Арабские Эмираты, эмират Эль-Фуджайра, окрестности отеля Fujairah Rotana Resort \& Spa, N 2530'57"/E 56²1'51", в пересыхающей луже, ручной сбор, Ит; *1 ф - 21.10.2017, КО, Жанакорганский р-н, окр. п. Байкенже, N 4353'32.41" Е 6655'19.32", в канале, мертвым, ИТ.

Примечание. Впервые был отмечен нами для юга страны (Temreshev, 2015 d). В настоящее время данные находки являются самыми северными для этого вида. Возможно, этим объясняется немногочисленность и редкость Н. pictus в Казахстане, поскольку здесь находится край его ареала. 


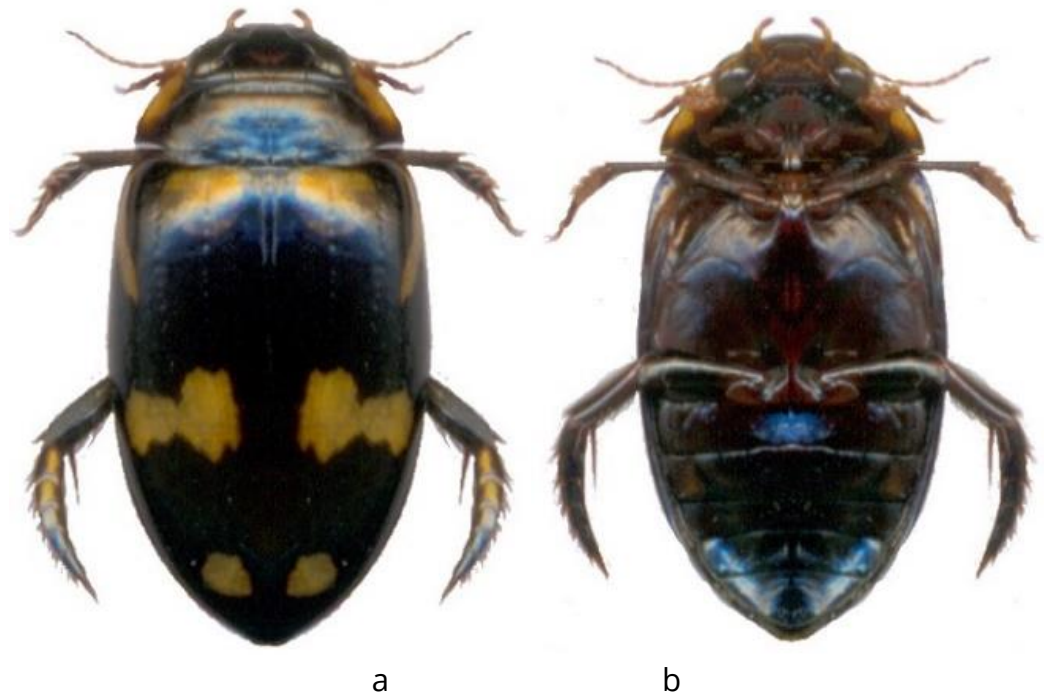

Рис. 6. Hydaticus pictus, внешний вид (а - вид сверху, b - вид снизу)

Hydaticus ponticus Sharp, 1882. Длина 9-10 мм. Тело короткое, округлое, выпуклое. Внешне очень похож на плавунцов из рода Rhantus Dejean 1833 из подсемейства Colymbetinae. Черный фон надкрылий состоит из крапинок, равномерно распределенных по поверхности надкрылий и чуть гуще - вдоль шва. На диске надкрылий крупные размытые точки. Переднеспинка желтоватая. Низ ржаво-красный (рис. 7). Во временных и постоянных стоячих и медленно текущих водоемах.

Распространение. Северная Африка, Аравийский п-ов, Ирак, Сирия, Малая Азия, Пакистан, Индия, Таджикистан, Туркменистан, Восточная область. - Южный Казахстан.

Материал: *1 \& - 27.05.2017, ЮКО, Отырарский р-н, ГНПП Сырдарья-Туркестан, 10 км СЗ п. Балтаколь, пойма р. Сырдарья, h=176 m, N 430 09' 20.1" E 67 50' 36.6", Юд; *1 оㅇ - 28.05.2017, ЮКО, Отырарский р-н, ГНПП СырдарьяТуркестан, 12 км Ю п. Коксарай, берег Сырдарьинского канала, h=191 m, N 42 32' 46.1" Е 68 10' 42.7", ЮД.

Примечание. В Каталоге плавунцов Палеарктики 2018 (Nilsson, Hájek, 2018b) данный вид для Казахстана не приводится вообще. Для юга страны впервые был отмечен в работе М. Пржевозны (Przewoźny, 2018). Поскольку вид был им указан в точке неподалеку от п. Шардара (Южно-Казахстанская область) рядом с границей Узбекистана, можно предполагать его обнаружение в будущем на территории данной страны. Находки Ю. Дьячкова, сделанные гораздо севернее, позволяют выдвинуть предположение о более широком распространении вида на территории Южно-Казахстанской области и возможности его нахождения в Кызылординской области, поскольку одна из них граничит с ее территорией.

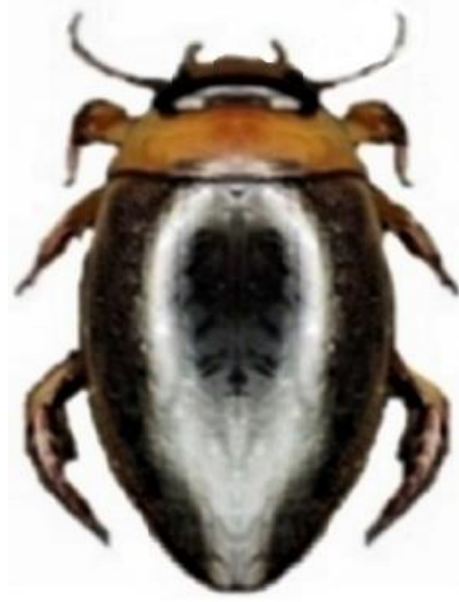

a

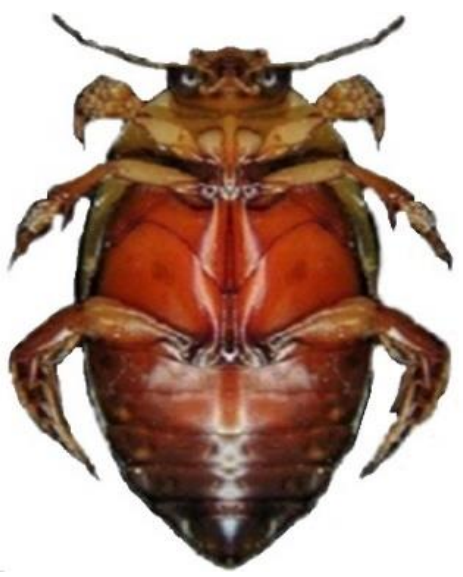

b

Рис. 6. Hydaticus ponticus, внешний вид (а - вид сверху, b - вид снизу)

\section{Обсуждение}

Всего для Казахстана в настоящее время отмечено 7 видов жуков-плавунцов из рода Hydaticus. Из них 4 вида (H. aruspex, H. continentalis, H. seminiger, H. transversalis) относятся к подроду Hydaticus, а 3 другие (H. grammicus, H. 
Temreshev, I.I. Review of the predaceous diving beetles of the genus Hydaticus.... Acta Biologica Sibirica, 2018, 4(3), 57-65

pictus и H. ponticus) - к подроду Prodaticus. Наиболее широко распространенным видом в Казахстане является $H$. grammicus, найденный практически по всей южной, юго-западной и юго-восточной части страны (Мангыстауская, Южно-Казахстанская, Жамбылская, Кызылординская, Алматинская области) и частично заходящий в ее центральную часть (юг Карагандинской области). Он же является наиболее многочисленным по результатам изученных материалов. H. pictus и H. ponticus встречаются единично только на крайнем юге республики (ЮжноКазахстанская и Кызылординская области), представляющем, по всей видимости, северную границу их ареала. $H$. aruspex приводится впервые для Казахстана, пока найден только на севере и в центральной части страны в единичном количестве. Возможно, его распространение на территории страны шире, но для выяснения этого нужны дополнительные исследования. H. continentalis является достаточно обычным видом в западной, северной и центральной частях Казахстана (Западно-Казахстанская, Актюбинская, Костанайская, Акмолинская, СевероКазахстанская области, север и центральная часть Карагандинской области). H. seminiger распространен довольно широко - найден в Костанайской, Акмолинской, Северо-Казахстанской, Павлодарской, Восточно-Казахстанской, Алматинской и Жамбылской областях, т.е. на севере, северо-востоке, в центральной части и на юге и юго-востоке страны, но повсеместно редок. Приводится впервые для Казахстана. H. transversalis отмечен в ЗападноКазахстанской, Мангыстауской, Акмолинской, Павлодарской и Алматинской областях Казахстана (запад, юго-запад, север, северо-восток и юго-восток), также редок. В будущем возможно дальнейшее уточнение видового состава и распространения видов рода Hydaticus на территории Казахстана.

\section{Благодарности}

Автор выражает благодарность за предоставленные сборы Ю. Дьячкову (Алтайский государственный университет, г. Барнаул, Российская Федерация) и П.А. Есенбековой (РГП Институт зоологии КН МОН РК, г. Алматы, Республика Казахстан), а также рецензенту статьи к.б.н. П.Н Петрову (Московский государственный университет им. М.В. Ломоносова) за ряд ценных замечаний.

\section{References}

Jacobson, G.G. (1905-1915). Beetles of Russia and Western Europe. St. Petersburg: Publication A.F. Devrient, 1024. (In Russian).

Meldebekov A.M., Kazenas V.L., Bajzhanov M.H. et al. (2011). Materialy k Kadastru zhivotnogo mira Almatinskoj oblasti. Chast' 1, Nasekomye. Almaty, Nur-Print (In Russian).

Miller K.B., Bergsten J., Whiting M.F. (2009). Phylogeny and classification of the tribe Hydaticini (Coleoptera:

Dytiscidae): partition choice for Bayesian analysis with multiple nuclear and mitochondrial protein-coding genes. Zoologica Scripta, 1, 34.

Nilsson A.N. (1981). The Fennoscandian species of the genus Hydaticus Leach (Coleoptera: Dytiscidae). Entomologica scandinavica, 12, 103-108.

Nilsson, A.N. \& Hájek, J. (2018a). A World Catalogue of the Family Dytiscidae. Version 1. I. 2018.

Nilsson, A.N. \& Hájek, J. (2018b). Catalogue of Palearctic Dytiscidae (Coleoptera). Internet version 2018-01-01.

Nilsson A.N., Holmen M. (1995). The aquatic Adephaga (Coleoptera) of Fennoscandia and Denmark. II. Dytiscidae. In: Fauna entomologica scandinavica, 32. Leiden; New York; Köln: E.J. Brill. 192.

Przewoźny, M. (2018). The first record of Hydaticus (Prodaticus) ponticus Sharp, 1882 (Coleoptera, Dytiscidae) from Kazakhstan. Acta entomologica silesiana, 26: (online 009), 1.

Temreshev, I.I. (2014a). Water beetles (Insecta, Coleoptera) of the State Natural National Park «lle-Alatau». KazNu Bulletin. Ecology series, 3 (42), 266-271. (In Russian).

Temreshev, I.I. (2014b). To the fauna and ecology of water beetles (Insecta, Coleoptera) of the Korgalzhin Biosphere Reserve. Proceed. of the International Scientific and Practical Conference held as part of the annual readings of the memorial member of the Academy of Sciences of the USSR A.A. Sludsky. 11-12 March 2014, Almaty, 532-538. (In Russian).

Temreshev, I.I. (2015a). To the fauna of water beetles (Insecta, Coleoptera) of the Dzhungar Alatau ridge. KazNu Bulletin. Ecology series, 1/2 (43), 591-595. (In Russian).

Temreshev, I.I. (2015b). Materials to the fauna aquatic bettles (Insecta, Coleoptera) of South Kazakhstan. Second Report. KazNu Bulletin. Biology series, 2 (1), 58-65. (In Russian).

Temreshev, I.I. (2015c). Water beetles (Insecta, Coleoptera) of the State National Natural Park "Sairam-Ugam" and adjacent territories. Proceed. IV Int. Sc. and Practical Conf. "The role of specially protected natural areas in biodiversity conservation" dedicated to the 20th anniversary of the state nature reserve "Prisursky". 21-24 October 2015, Cheboksary, Russia. Scientific works of the state nature reserve "Prisursky", 30, 1, 248-252. (In Russian).

Temreshev, I.I. (2015d). First records of Hydaticus (Prodaticus) pictus Sharp, 1882 (Coleoptera, Dytiscidae) in Kazakhstan. Euroasian entomological journal, 14 (6), 554. (In Russian).

Temreshev, I.I. (2016). To the fauna and distribution of aquatic beetles (Insecta, Coleoptera) of South Kazakhstan. Acta Biologica Sibirica, 2 (4), 15-28. (In Russian).

Temreshev I.I. (2018). Water beetles (Insecta, Coleoptera) of the Jongar-Alatau State National Natural Park. Water Bioresources and Aquaculture in the South of Russia: Proceed. of the All-Russian Sc. and Practical Conf. timed to the 20th 
anniversary of the opening in the Kuban state un-those areas of training "Aquatic Bioresources and Aquaculture". Ed. G.A. Moscul. Krasnodar: Kuban State University, 2018, 259-265. (In Russian).

Temreshev, I.I., Esenbekova P.A. (2013). Materials for fauna of aquatic beetles (Insecta, Coleoptera) of South Kazakhstan. KazNU Bulletin. Ecology series, 3 (39), 130-138. (In Russian).

Temreshev, I.I., Kolov, S.V. (2013). To the fauna of water beetles Karatau ridge and adjacent territories Proceed. of the International Scientific and Practical Conference held as part of the annual readings of the memorial member of the Academy of Sciences of the USSR A.A. Sludsky. 11-12 March 2013, Almaty, 300-306. (In Russian).

Tsalolikhin, S.Y. (eds). (2001). Freshwater invertebrates of Russia and adjacent territories. 5. Higher insects (caddisflies, moths, beetles, lacewings, megaloptera, hymenoptera). St. Petersburg, 836. (In Russian).

Zaitzev, P.A. (1953). Beetles. Predatory diving and whirligig beetles. Fauna SSSR, 58. M.-L., Ed. Academy of Sciences of the USSR, 378. (In Russian).

\section{Citation:}

Temreshev, I.I. (2018). Review of the predaceous diving beetles of the genus Hydaticus Leach, 1817 (Coleoptera: Dytiscidae) of Kazakhstan. Acta Biologica Sibirica, 4 (3), 57-65.

Submitted: 18.02.2018. Accepted: 05.05.2018

cross ref http://dx.doi.org/10.14258/abs.v4i3.4369

(C) 2018 by the authors. Submitted for possible open access publication under the terms and conditions of the Creative Commons Attribution (CC BY) license (http://creativecommons.org/licenses/by/4.0/). 